\title{
Initial development of bottle gourd as a function of nitrogen rates
}

\section{Desenvolvimento inicial do caxizeiro em função de doses de nitrogênio}

\section{Benedito Rios de OLIVEIRA ${ }^{1}$; Aline dos Anjos SOUZA²; Celicleide Quaresma LOBO ${ }^{3}$ Uasley Caldas de OLIVEIRA ${ }^{4}$; Anacleto Ranulfo SANTO ${ }^{5}$}

${ }^{1}$ Autor para correspondência; Mestre em Eng. Agrícola, Universidade Federal do Recôncavo da Bahia, Cruz das Almas-BA,
E-mail: benedito.ta@hotmail.com.
${ }^{2}$ Mestre em Solos e Qualidade de Ecossistema, Universidade Federal do Recôncavo da Bahia, Cruz das Almas-BA, E-mail:
eng.alinesouza@gmail.com.
${ }^{3}$ Mestranda em Solos e Qualidade de Ecossistemas, Universidade Federal do Recôncavo da Bahia, Cruz das Almas - BA, E-
mail: cleidequaresma@hotmail.com.
${ }^{4}$ Mestre em Solos e Qualidade de Ecossistema Universidade Federal do Recôncavo da Bahia Cruz das Almas - BA, E-mail:
uasley@gmail.com.
${ }^{5}$ Professor Titular pela Universidade Federal do Recôncavo da Bahia Cruz das Almas, E-mail: anacleto@ufrb.edu.br. Recebido em: 08-05-2019; Aceito em: 19-07-2019

\begin{abstract}
Bottle gourd (Lagenaria siceraria) is a little known cucurbit, which is well accepted by consumers and is used in cooking mainly in the northeastern and southern regions of Brazil. This study evaluates the behavior of bottle gourd subjected to nitrogen rates in a greenhouse. The experimental design was completely randomized with five treatments and six replicates. The treatments consisted of five nitrogen rates equivalent to 0, 70, 140, 210, and $420 \mathrm{mg} \mathrm{L}^{-1}$. The following were evaluated: plant height, stem diameter, number of leaves, root dry mass, stem dry mass, leaf dry mass, total dry mass, root/shoot ratio, and chlorophyll a and b contents. Nitrogen rates influenced all studied variables. Greater plant height and stem diameter were obtained with 277 and $282 \mathrm{mg} \mathrm{L}^{-1} \mathrm{~N}$, respectively. The highest nitrogen rate provided higher root growth. The results showed that the bottle gourd crop is very responsive to nitrogen fertilization during its initial growth.
\end{abstract}

Additional keywords: cucurbits; edible gourd; Lagenaria siceraria; nitrogen fertilization.

\section{Resumo}

O caxizeiro (Lagenaria siceraria) é uma cucurbitácea ainda pouco conhecida, apresenta muita aceitação pelos consumidores, sendo utilizada na culinária principalmente nas regiões Nordeste e Sul do Brasil. O objetivo do trabalho foi avaliar o comportamento do caxizeiro submetido a doses de nitrogênio em casa de vegetação. $O$ delineamento experimental foi inteiramente casualizado, com cinco tratamentos e seis repetições. Os tratamentos consistiram em cinco doses de nitrogênio equivalentes a 0; 70; 140; 210 e $420 \mathrm{mg} \mathrm{L}^{-1}$. Foram avaliados a altura, diâmetro do caule, número de folhas, massa seca da raiz, massa seca do caule, massa seca de folhas, massa seca total, razão raiz/parte aérea e os índices de clorofila a e b. As doses de nitrogênio influenciaram todas as variáveis estudadas. Maiores altura e diâmetro do caule foram obtidos com 277 e $282 \mathrm{mg} \mathrm{L}^{-1}$ de N, respectivamente. A dose mais elevada de nitrogênio proporcionou maior crescimento de raízes. Os resultados demonstraram que o caxizeiro é uma cultura bastante responsiva à adubação nitrogenada durante o crescimento inicial.

Palavras-chave adicionais: adubação nitrogenada; cucurbitáceas; Lagenaria siceraria; porango comestível.

\section{Introduction}

Bottle gourd (Lagenaria siceraria) is a plant of the Cucurbitaceae family. This crop is not grown on a large scale and is considered a nontraditional vegetable because it is not regularly consumed (Filgueira, 2008). Its edibility is related to the absence of bitterness, that is, it does not have the substance called cucurbitacin. The fruit is popularly known as "caxi" in São Paulo State and "chuchu porongo" in Rio Grande do Sul State (Trevisol, 2015).

It is important that the bottle gourd presents good initial growth with expansion of branches, since this process of physiological development is fundamental to obtain more fruits in a short time. The main branch and two leaves appear soon after seed germination. The plants have a primary branch that originates in the seed hypocotyl, from which the other branches emerge (Trevisol, 2015).

Bottle gourd production is mainly carried out by small producers and traditional family farming communities in the northeastern and "agreste" region of Minas Gerais. It is a food rich in vitamins and minerals; $100 \mathrm{~g}$ of fruit has 20 calories, $4.3 \mathrm{~g}$ carbohydrates, 1.2 $\mathrm{g}$ proteins, $0.2 \mathrm{~g}$ lipids, $2 \mathrm{~g}$ sodium and $1.9 \mathrm{~g}$ fibers (Philippi, 2002). 
Unripe bottle gourd fruits have a tender and pubescent peel and a pulp with high moisture content. Harvesting is performed until epicarp lignification. When ripe, these fruits become glabrous, with a thick and lignified bark; at this developmental stage there is a reduction in pulp moisture, making the fruit unfit for consumption (Melo \& Azevedo Filho, 2003).

The fruits are usually consumed in sautéed, stuffed, or fried meats. Despite having relevant socioeconomic importance, this crop is still poorly researched. There are rare records of studies on bottle gourd and there are few scientifically based agronomic recommendations for the crop regarding its nutritional needs, especially for nitrogen.

Nitrogen deficiency in crops decreases the photosynthetic rate, also affecting transpiration, stomatal conductance, and chlorophyll content. This demonstrates that limiting nitrogen availability influences primary plant metabolism (Zhu et al., 2014). However, when nitrogen deficiency begins slowly, plants may have thin and woody stems. The woody appearance may be due to carbohydrate accumulation, which was not used in the synthesis of amino acids or other nitrogen compounds (Hawkesford et al., 2012).

On the other hand, excess nitrogen can be negative to the plant, since shoots grow more than roots, leaving plants subject to water and nutrient deficiency, especially phosphorus and potassium (Gonsalves, 2009). Increased nitrogen supply may cause self-shading due to excessive vegetative growth and may cause changes in microclimate conditions (Corrêa et al., 2016). As seen, both nitrogen excess and deficiency can affect crop development, which makes proper dose application crucial. Notwithstanding, the information available for the cultivation of bottle gourd is scarce. Thus, we sought to obtain the ideal nitrogen rate for the crop, analyzing its initial development both in the absence of and with increasing rates of this element. In this context, this study evaluated the effects of nitrogen rates on the initial development and dry mass production of bottle gourd plants.

\section{Materials and methods}

The experiment was conducted in a greenhouse in the experimental area of the Center for Agricultural, Environmental, and Biological Sciences of the Federal University of Recôncavo da Bahia (UFRB) from April to June 2017, in Cruz das Almas-BA, Brazil. This area is located at an altitude of $225 \mathrm{~m}$, at coordinates $12^{\circ} 39^{\prime} S$ and $39^{\circ} 05^{\prime} \mathrm{W}$. According to the Köppen-Geiger classification, the local climate is tropical hot and humid, Aw to Am. The average temperature in the experimental period was $22^{\circ} \mathrm{C}$, with $126.5 \mathrm{~mm}$ rainfall.

Bottle gourd plants were sown in polystyrene trays filled with washed sand. Distilled water was applied daily during germination and seedling development. At 10 days after sowing, when plants had four leaves, they were transplanted to pots with
$3.0 \mathrm{dm}^{3}$ capacity, which were filled with washed sand and commercial substrate vermiculite, in the ratio of $2 \mathrm{dm}^{3}: 1 \mathrm{dm}^{3}$, respectively.

Seedlings were irrigated daily with $50 \mathrm{~mL}$ of distilled water. Plant nutrition was granted five days after transplantation by providing $100 \mathrm{~mL}$ of nutrient solution every 72 hours. In the first five days after transplantation, a $50 \%$ nutrient solution was used. Subsequently, the solution was used at standard concentration. At times when the nutrient solution was applied, no irrigation was performed.

The nutrient solution was obtained from the basic solution described by Hoagland \& Arnon (1950), with balanced nitrogen rates in the form of ammonium nitrate and calcium nitrate. Calcium rates refer to the nutrient solution of Hoagland \& Arnon (1950). Macronutrient sources used were $\mathrm{Ca}\left(\mathrm{NO}_{3}\right)_{2}, \mathrm{KNO}_{3}, \mathrm{KCl}$, $\mathrm{KH}_{2} \mathrm{PO}_{4}, \mathrm{MgSO}_{4}, \mathrm{CaCl}_{2}$, and $\mathrm{NH}_{4} \mathrm{NO}_{3}$. Micronutrients used to make up the stock solution were $\mathrm{H}_{3} \mathrm{BO}_{3}$ (2.8 mg. L-1), $\mathrm{ZnSO}_{4} .7 \mathrm{H}_{2} \mathrm{O}\left(0.22 \mathrm{mg} \mathrm{L}^{-1}\right), \mathrm{MnSO}_{4} .4 \mathrm{H}_{2} \mathrm{O}$ $\left(3 \mathrm{mg} \mathrm{L}^{-1}\right), \mathrm{CuSO}_{4} .5 \mathrm{H}_{2} \mathrm{O}\left(0.08 \mathrm{mg} \mathrm{L}^{-1}\right), \mathrm{H}_{2} \mathrm{MoO}_{4} . \mathrm{H}_{2} \mathrm{O}$ (0.02 $\left.\mathrm{mg} \mathrm{L}^{-1}\right)$, and $1 \mathrm{ml} \mathrm{L}^{-1} \mathrm{Fe}-E D T A$ solution. The ideal Hoagland \& Arnon (1950) solution is $210 \mathrm{mg} \mathrm{L}^{-1}$ nitrogen, and this rate was used to propose treatments.

The experimental design was completely randomized with five treatments and six replicates. The experimental unit consisted of a pot with a seedling. Treatments consisted of five nitrogen rates $(0,70,140$, 210, and $420 \mathrm{mg} \mathrm{L}^{-1}$ ).

At 35 days after transplantation, the following were evaluated: plant height $(\mathrm{PH})$, stem diameter (SD), number of leaves (NL); root dry mass (RDM); stem dry mass (SDM); leaf dry mass (LDM); total dry mass (TDM); root/shoot ratio (RSR); chlorophyll indices $a$ and $b$. Measurements were made with the aid of $a$ ruler and a digital caliper.

Stem diameter was measured at the base of the plant neck, with an accuracy of $0.1 \mathrm{~cm}$. The number of leaves (NL) was determined by manual counting, considering only open leaves with dimensions from $0.06 \times 0.05 \mathrm{~m}$. Plant height was measured with a ruler from the neck to the apex (terminal bud) of the plant. Moreover, roots were collected and washed with water to remove the substrate. Plants were separated into root, stem, and leaf components, and dried in a forced air circulation oven at $65^{\circ} \mathrm{C} \pm 3^{\circ} \mathrm{C}$ for 72 hours until constant mass.

Leaf dry mass (LDM), stem dry mass (SDM), root dry mass (RDM), and total dry mass (TDM) were determined using an analytical balance accurate to $10^{-3} \mathrm{~g}$. Chlorophyll content data were collected using an electronic meter (Falker, model CFL1030), with readings taken on three leaves from the middle third of each seedling according to Peixoto et al. (2011). Root/shoot ratio (RSR) was obtained by the ratio between RDM and SDM (Hunt, 1982; Benincasa, 2004).

Data were submitted to analysis of variance with the aid of the computational statistical program " $R$ " (R Development Core Team, 2019). Due to the level of significance, regression was applied to evaluate the effects of nitrogen rates. 


\section{Results and discussion}

There was a significant effect $(P<0.05)$ of nitrogen rates on all studied variables. Plant height, number of leaves, and stem diameter were fitted to a quadratic equation, with maximum values of $28.05 \mathrm{~cm}$, $12 \mathrm{~mm}$, and $6 \mathrm{~mm}$ at the rates of 277,297 , and $282 \mathrm{mg} \mathrm{L}^{-1} \mathrm{~N}$, respectively (Figure 1 ).
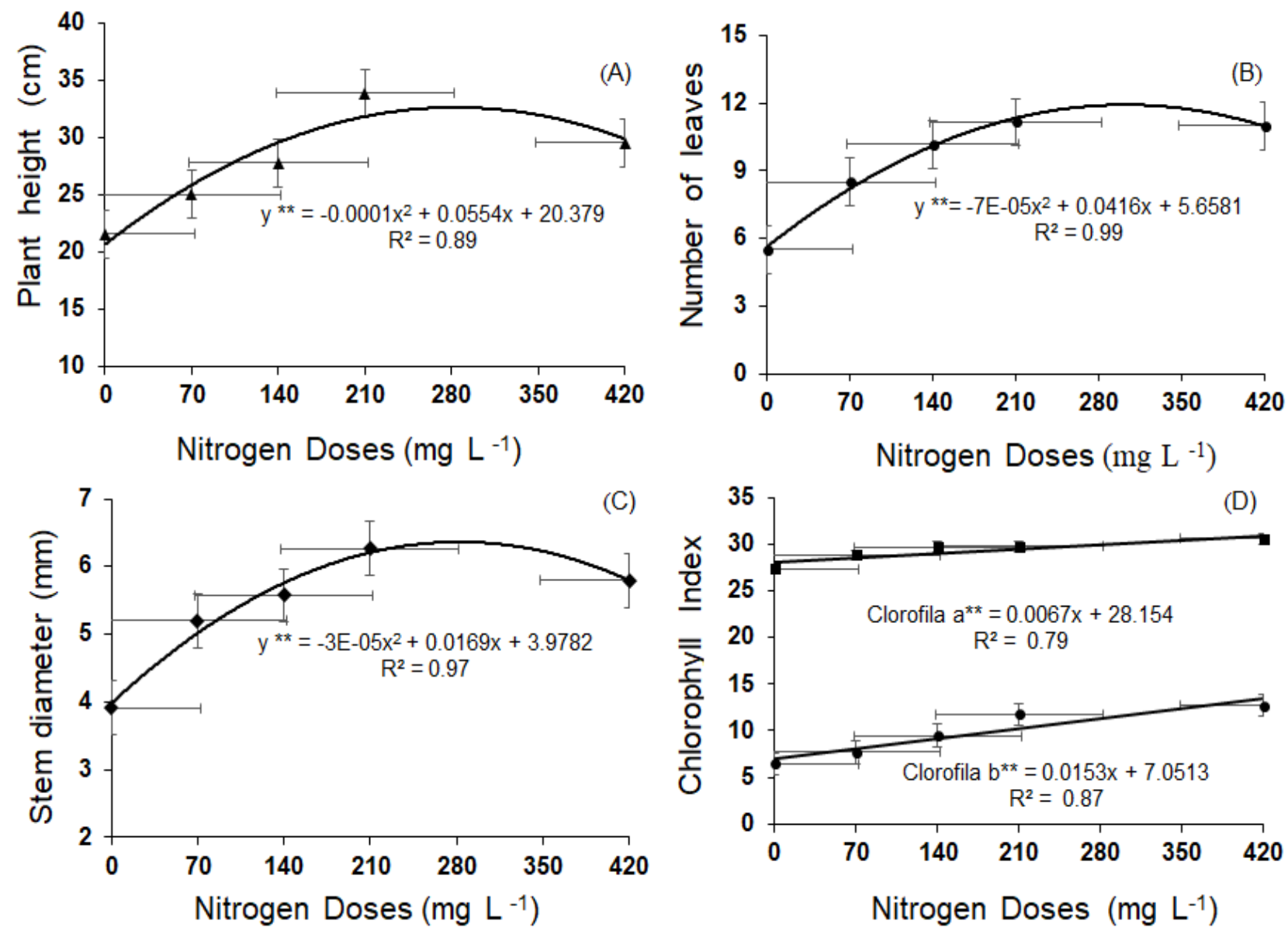

Figure 1 - Plant height (A), number of leaves (B), stem diameter (C) and chlorophyll $a$ and $b$ indices of the bottle gourd as a function of nitrogen rates.

When studying species from the same family, Silva (2012) observed that stem diameter fitted a quadratic equation as a function of nitrogen rates at 53 days after plant emergence, with maximum stem diameter at the rate of $81.25 \mathrm{mg} \mathrm{L}^{-1}$. Bottle gourd presented a different behavior, showing to be more demanding in nitrogen, requiring higher rates to reach its growth potential.

Nitrogen acts on plant growth and development, modifying the source-drain relationship and, consequently, the disposition of assimilates between vegetative and reproductive plant organs. In cucurbits, the increase of nitrogen rate up to a certain limit allows increased plant leaf area, therefore interfering with the production of photoassimilates (Queiroga et al., 2007).

When studying the production and quality of watermelon fruits with nitrogen application via fertigation, Andrade Junior et al. (2006) found that total and commercial yield increased significantly with nitrogen increase, following a quadratic response model.

There was a significant effect $(P<0.05)$ of nitrogen rates on chlorophyll $a$ and $b$ indices (Figure 1D). An increasing linear behavior was observed for these variables as a function of nitrogen rates, with an increase of 9 and $48 \%$, respectively. Thus, it is evident the great demand for nitrogen by bottle gourd seedlings. According to Fontes \& Araújo (2007), the increase of nitrogen supply to plants up to a certain limit allows the increase in chlorophyll indices, and green color intensity in plant leaves is linked to $\mathrm{N}$ participation in the synthesis and structure of chlorophyll molecules.

Bottle gourd showed deficiency symptoms such as yellowing of old leaves and necrosis on the edges up to the rate of $140 \mathrm{mg} \mathrm{L}^{-1}$ nitrogen (Figure 2), differentiating from the study of Silva (2012), with other cucurbits. When working with melon, Silva (2012) observed nitrogen deficiency up to $40 \mathrm{mg} \mathrm{L}^{-1}$ nitrogen, in which plants showed chlorosis from $30 \mathrm{DAE}$, primarily in the older leaves, the intensity being inversely influenced by nitrogen rates. 


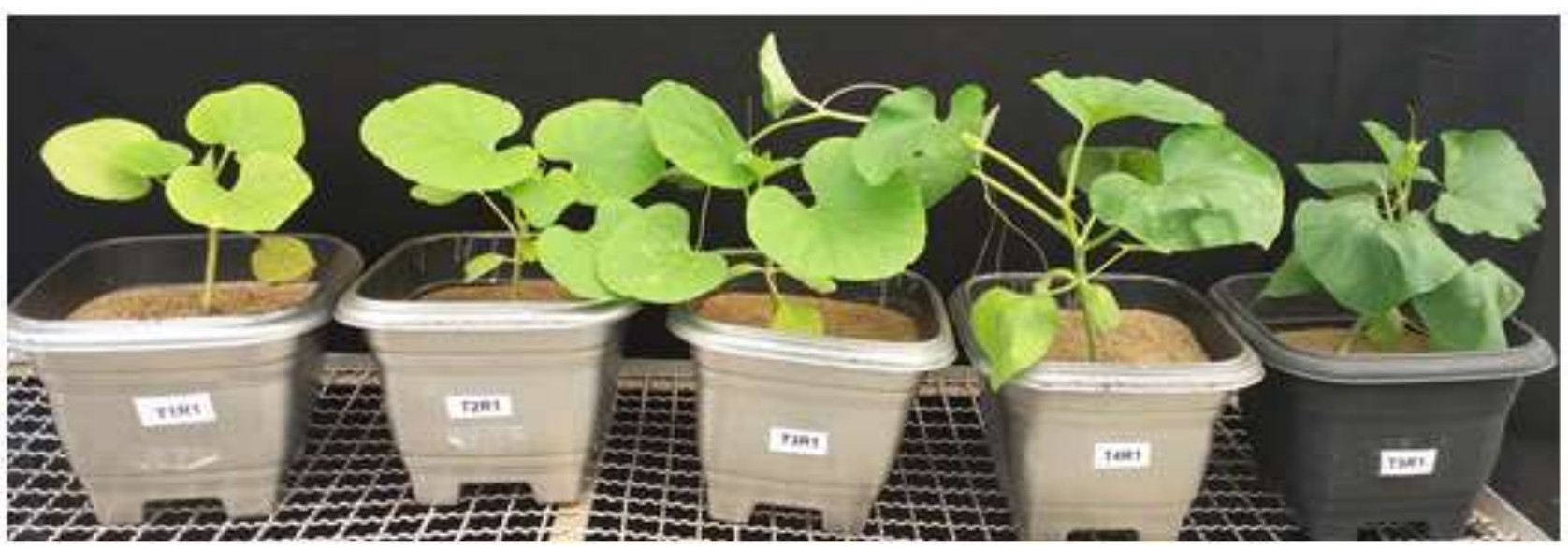

Figure 2 - Chlorosis in leaves of bottle gourd plants submitted to nitrogen rates (from left to right: 0, 70, 140, 210, and $420 \mathrm{mg} \mathrm{L}^{-1}$ ).

Nitrogen rates had a significant effect $(P<0.05)$ on shoot dry mass (Figure $3 \mathrm{~A}$ ), with a maximum estimated value of $3 \mathrm{~g}$ at the maximum rate, $257 \mathrm{mg} \mathrm{L}^{-1} \mathrm{~N}$. Root dry mass (Figure 3B) had a linear behavior, with a $27 \%$ increase as a function of nitrogen rates. Regarding total dry mass, $3 \mathrm{~g}$ was obtained with the maximum rate, $250 \mathrm{mg} \mathrm{L}^{-1} \mathrm{~N}$ (Figure $3 \mathrm{C}$ ).
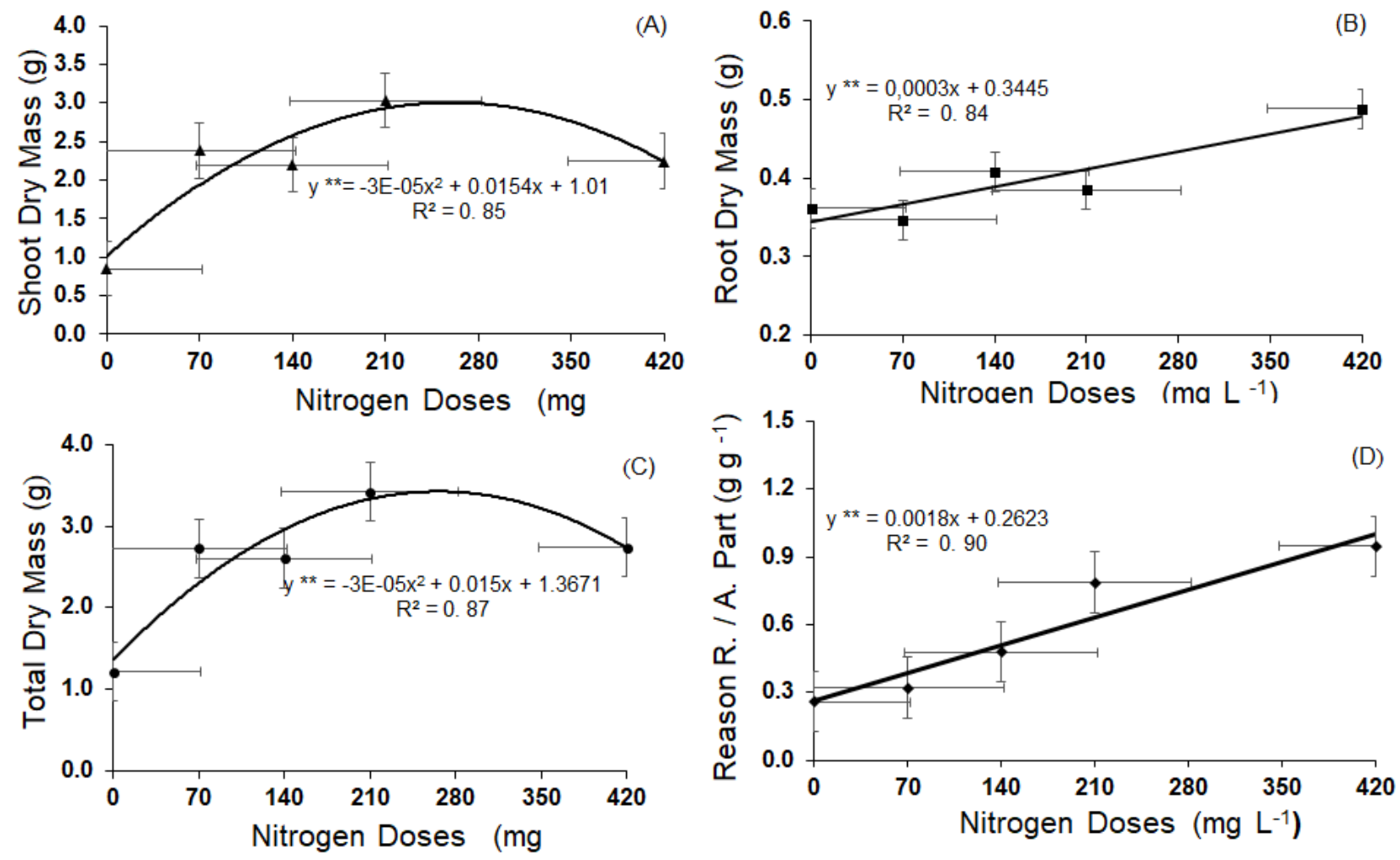

Figure 3 - Shoot dry mass (A), root dry mass (B), total dry mass (C) and reason root / aerial part (D) of bottle gourd plants as a function of nitrogen doses.

According to Corrêa \& Gouveia (2014), nitrogen deficiency in young plants compromises development and reduces dry mass accumulation. When evaluating macronutrient contents in the pumpkin crop, these authors observed that nitrogen was the second most abundant nutrient in this cucurbit. Being from the same family, bottle gourd may present a similar performance. According to Cantarella (2007), nitrogen is directly related to the photosynthetic capacity of plants.
Consequently, its supply in adequate quantities ensures greater growth. Notwithstanding, when nitrogen is high in the external part of the root, it is absorbed by low affinity carriers. This effect allows nitrogen to be absorbed at levels higher than the plant's metabolic capacity, which may negatively affect plant development as a result of intoxication (Souza \& Fernandes, 2006). This fact may justify the quadratic behavior as a function of nitrogen rates in the dry mass 
of bottle gourd plants, with differences in development and imbalance between plant organs as a function of these rates.

The root/shoot ratio showed an increasing linear behavior, increasing by $74 \%$ with the highest rate, $420 \mathrm{mg} \mathrm{L}^{-1}$ (Figure 3D). According to Pedó et al. (2014), nitrogen fertilization allows lower leaf mass ratios, indicating that a smaller amount of dry mass was allocated to leaves with increasing nitrogen rates. Figure 4 shows the fractional allocation of bottle gourd mass. At the rate of $0 \mathrm{mg} \mathrm{L}^{-1}$ nitrogen, leaf dry mass corresponded to $66.42 \%$ of the total dry mass. The absence of nitrogen limited bottle gourd root growth, so with increasing rates there was a decrease in leaf dry mass and an increase in root dry weight. At $420 \mathrm{mg} \mathrm{L}^{-1}$ nitrogen, leaf dry mass and root dry mass corresponded to $42.78 \%$ and $45.19 \%$ of the total dry mass, respectively. Higher nitrogen rates provided greater root development in plants. This indicates that bottle gourd has higher growth with increasing nitrogen rates.

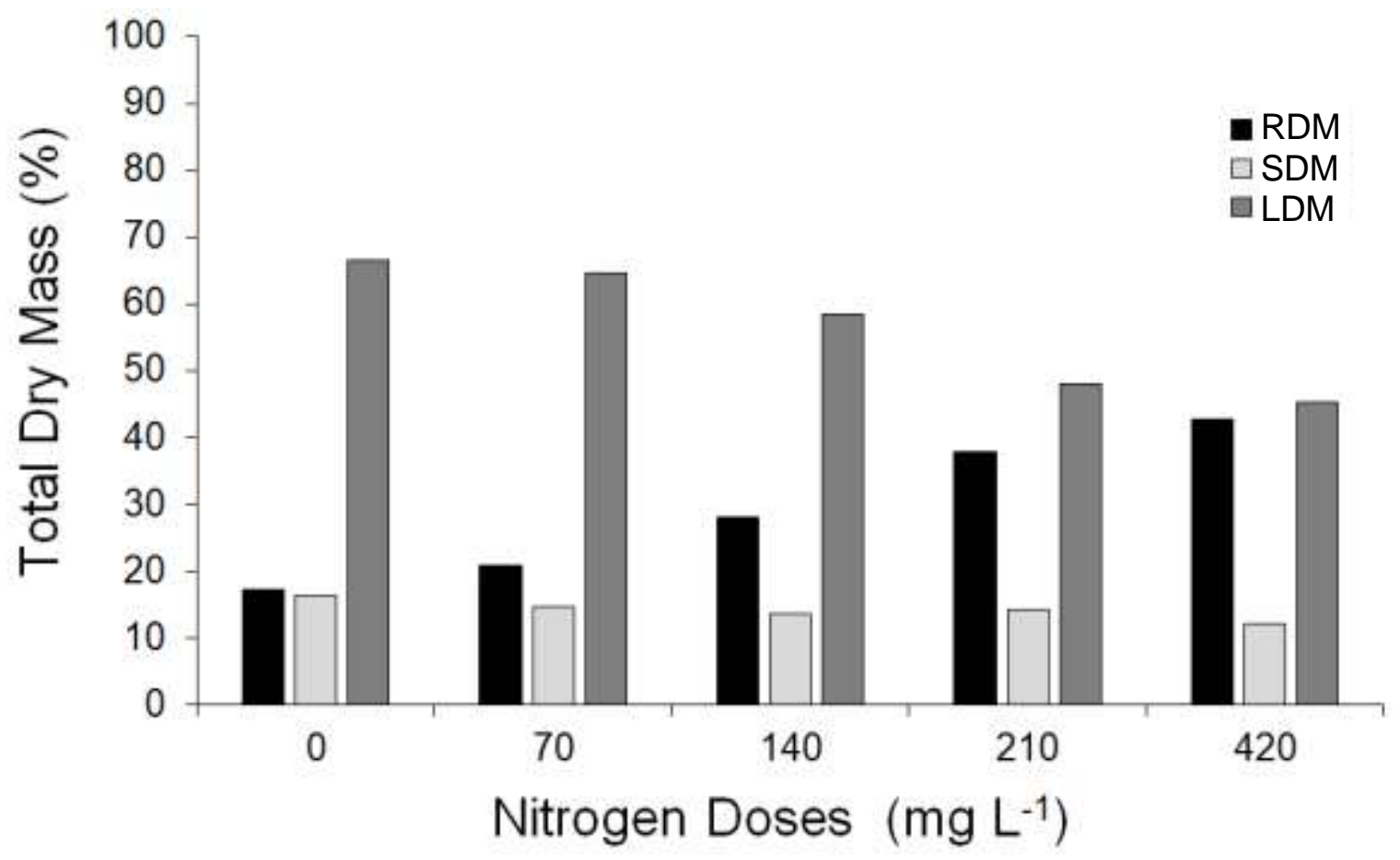

Figure 4 - Percentage of dry mass of root (RDM), stem (SDM) and leaf (LDM) of bottle gourd plants in a total of dry mass as a function of nitrogen rates.

According to Grangeiro et al. (2007), the nitrogen absorbed by roots is assimilated to meet the needs of plant nitrogen compounds during the crop cycle, thus there is a link between nitrogen uptake and the increase in plant dry weight. In this study, the ideal rate for the initial development of bottle gourd was $210 \mathrm{mg} \mathrm{L}^{-1}$ nitrogen.

The root/shoot ratio is a very important aspect because it indicates the ratio between stem and leaf growth following root expansion. In many cases, stem growth can be influenced by luminosity or plant etiolation (Vidal et al., 2012).

\section{Conclusions}

Increased nitrogen concentration in the nutrient solution influences the initial growth of bottle gourd plants.

The rate that provided the highest total dry weight accumulation $(3.2 \mathrm{~g})$ was $250 \mathrm{mg} \mathrm{L}^{-1} \mathrm{~N}$. In turn, the rate of $420 \mathrm{mg} \mathrm{L}^{-1} \mathrm{~N}$ promotes better root/shoot ratio in bottle gourd seedlings.

\section{References}

Andrade Júnior AS, Dias NS, Junior LGMF, Ribeiro VQ, Sampaio DB (2006) Produção e qualidade de frutos de melancia à aplicação de nitrogênio via fertirrigação. Revista Brasileira de Engenharia Agrícola e Ambiental 10(4):836-841.

Benincasa MMP (2004) Análise de crescimento de plantas: noções básicas. Jaboticabal: FUNEP. 42 p.

Cantarella H (2007) Nitrogênio. In: Novais RF, Alvarez VH, Barros NF, Fontes RLF, Cantarutti RB, Neves JCL Fertilidade do solo. Viçosa: Sociedade Brasileira de Ciência do Solo. p.471-537.

Corrêa CV, Sllvero NEQ, Antunes WLP, Cimó L, Redigolo MV, Cardoso ALL (2016) Acúmulo de nutrientes em abóbora em função do número de plantas e aplicação de nitrogênio em cobertura. Revista Cultivando o Saber 9(2):180-191. 
Corrêa CV, Gouveia All (2014) Teores de macronutrientes em função do número de plantas por cova e doses de nitrogênio em cobertura na produção de abóbora. Revista Cultivando o Saber 7(4):343-372.

Filgueira FAR (2008) Novo manual de olericultura: agrotecnologia moderna na produção e comercialização de hortaliças. Viçosa:UFV. 421 p.

Fontes PCR, Araújo C (2007) Adubação nitrogenada de hortaliças: princípios e práticas com o tomateiro. Viçosa: UFV. 148p.

Gonsalves MVL (2009) Doses de N e K aplicadas via fertirrigação e espaçamento entre plantas influenciando e desenvolvimento, e produtividade e as relações hídricas em melancieira com e sem sementes. UNESP (Dissertação de mestrado em Agronomia).

Grangeiro LC, Negreiros MZ, Souza BS, Azevêdo PE, Oliveira SL, Medeiros MA (2007) Acúmulo e exportação de nutrientes em beterraba. Ciência e Agrotecnologia 31(2):267-273.

Hawkesford M (2012) Functions of macronutrients: potassium. In: Marschner H. (ed) Mineral Nutrition of Higher Plants. 3 ed. cap. 6. 178-189p.

Hoagland DR, Arnon DI (1950) The waterculture method for growing plants without soil. Berkeley, CA: Agricultural Experimental Station. University of California (Circular 347).

Hunt R (1982) Plant growth curves: the functional approach to plant growth analysis. London: E. Arnold. $248 p$.

Melo AMT, Azevedo Filho JA (2003) Caracterização agronômica e morfológica de genótipos de cabaça. Horticultura Brasileira 21(2):350.

Pedó T, Aumonde TZ, Martinazzo EG, Villela FA (2014) Análise de crescimento de plantas de rabanete submetidas a doses de adubação nitrogenada. Bioscience Journal 30(1):1-7.
Peixoto CP, Cruz TV, Peixoto MFSP (2011) Análise quantitativa do crescimento de plantas: Conceitos e Prática. Enciclopédia Biosfera 7(13):51-76.

Philippi TS (2002) Tabela de composição dos alimentos: suporte para decisão nutricional.135 p.

Queiroga RCF, Puiatti M, Fontes PCR, Cecon PR, Finger FL (2007) Influência de doses de nitrogênio na produtividade e qualidade do melão Cantalupensis sob ambiente protegido. Horticultura Brasileira 25(4): 550556.

R Core Team (2019) R: A language and environment for statistical computing $\mathrm{R}$ Foundation for Statistical Computing, Vienna, Austria. Disponível em: URL https://www.R-project.org/. Acesso Janeiro 2019.

Silva MC (2012) Melão rendilhado em ambiente protegido submetido às doses de nitrogênio e potássio em Rondonópolis-MT. Universidade Federal de Mato Grosso campus Universitário de Rondonópolis (Mestrado Engenharia Agrícola, área de concentração: Engenharia de Sistemas Agrícolas).

Souza SR, Fernandes MS (2006) Nutrição mineral de plantas. Sociedade Brasileira de Ciência do Solo. 432p.

Trevisol W (2015) A cultura do porongo. 73p.

Vidal RA, Trezzi MM, Kozlowski LA, Prates MVB, Cieslik LF, Merotto Junior A (2012) Initialism as a mechanism of weed interference: can a crop plant be blinded Planta Daninha 30(3):469-475.

Zhu Y, Fan X, Hou X, Wu J, Wang T (2014) Effect of different levels of nitrogen deficiency on switchgrass seedling growth. The Crop Journal 2(4):223-234. 